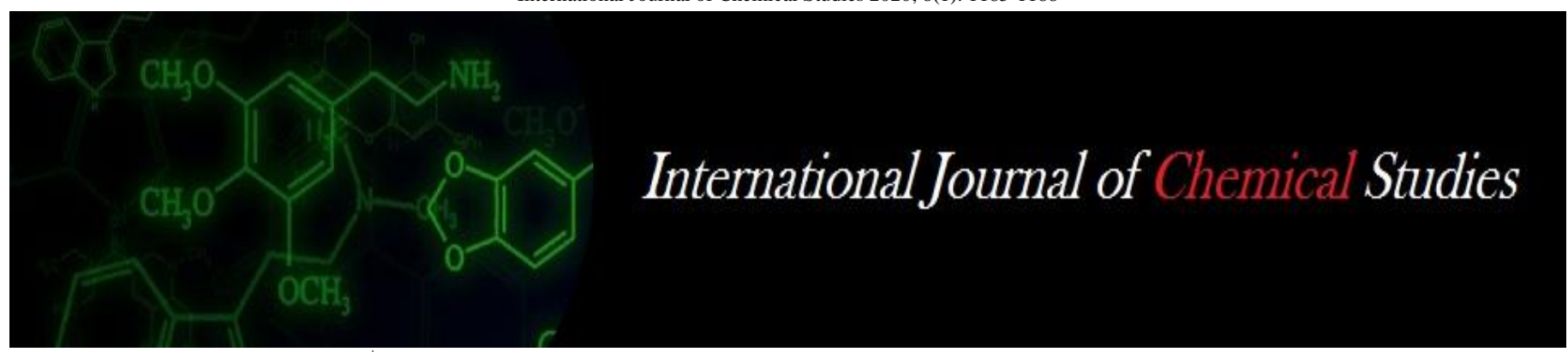

P-ISSN: 2349-8528

E-ISSN: 2321-4902

IJCS 2020; 8(1): 1185-1188

(C) 2020 IJCS

Received: 22-11-2019

Accepted: 24-12-2019

KV Kale

Researcher, Scholar, Deptt. of

Extension Education,

Dr. Panjabrao Deshmukh Krishi

Vidyapeeth, Akola,

Maharashtra, India

\section{BN Hingne}

Agricultural Assistant,

Vasantrao Naik Marathwada

Krishi Vidyapeeth, Parbhani,

Maharashtra, India

\section{MA Raut}

Agricultural Assistant,

Vasantrao Naik Marathwada

Krishi Vidyapeeth, Parbhani,

Maharashtra, India

\section{DM Mankar}

Research Guide \& Associate Professor, Deptt. of Extension Education, Dr. Panjabrao Deshmukh Krishi Vidyapeeth, Akola, Maharashtra, India

Corresponding Author:

\section{KV Kale}

Researcher, Scholar, Deptt. of

Extension Education, Dr.

Panjabrao Deshmukh Krishi

Vidyapeeth, Akola,

Maharashtra, India

\section{To ascertain the knowledge level of farm input dealers about the use of farm input they deal and to determine the training needs and decide the areas of training}

\author{
Komal V Kale, Bharat N Hingne, Mangesh A Raut and Dr. DM Mankar
}

DOI: $\underline{\text { https://doi.org/10.22271/chemi.2020.v8.i1p.8413 }}$

\begin{abstract}
The present study on Training Needs of Farm Input Dealers About Farm Input was conducted in Akola and Wardha districts of Vidarbha region of Maharashtra state. For this study 70 dealers were purposively selected from ten tahsils from both districts with the help of proportionate sampling method. The data were collected with the help of structured interview schedule. Personal interview technique was used for data collection. The results revealed that majority $(48.58 \%)$ respondents were observed in 'middle' age category that is up to 42.52 years having 71.42 per cent respondents were found in 'medium' category of experience in dealership. About 64.28 per cent of respondents educated up to 'graduate' level of education and most of them had 'medium' land holding (27.14\%). Majority of 81.42 per cent respondents had annual income found in the range of Rs. Up to Rs. 3,47,000 to 7,34,000/-. Maximum number of the respondents having 'medium' level of source of information $(67.14 \%)$, followed by 61.42 per cent of respondents had 'medium' level of extension contact and social participation (60.00). Majority (70.00\%) of the respondents have 'medium' level of cosmopoliteness and innovativeness (54.28\%). All 100.00 per cent farm input dealers did 'not received' training on various aspect related to fertilizers, seeds, insecticides, pesticides and implements. Majority (68.00\%) of the farm input dealers had 'medium' level of knowledge related to use of seeds, fertilizers and pesticides.

In respect of training needs, farm input dealers had expressed 'high' training needs on seed technology, different insecticides and pesticides its contents, concentration to be used storage and keeping quality of insecticides, pesticides and fertilizers, etc. (97.14\%), followed by advanced technical information of new agricultural inputs $(94.28 \%)$, training about credit/financial management and government policies, rules regulations and taxes related agriculture having 98.57 per cent. '(90.00\%) competition with other input dealers followed by transportation $(82.85 \%)$, non availability of clients and inadequate credit facilities $(72.85 \%)$, non availability of labors (71.42\%), lack of knowledge about mode of chemicals (67.14\%), non availability of selling organizations $(60.00 \%)$, and sometime prices of agricultural input goes high $(54.28 \%)$ ', were the major constraints faced by them. Results of relational analysis revealed that variables such as land holding, annual income, source of information, extension contact, cosmopoliteness and innovativeness were found positively and significantly correlated with training needs of farm input dealers. In case of other variables like age, social participation and knowledge had shown negative nonsignificant relationship with training needs of farm input dealers.
\end{abstract}

Keywords: Knowledge level, determine, training needs, decide

\section{Introduction}

Agriculture is the backbone of Indian economy since 1960, when this sector was in humble state. The statement still holds true when the country has gained self-reliance in agricultural production. The Indian population goes to above one billion and about 70.00 per cent of it is dependent on agriculture directly or indirectly, with 75.00 per cent of marginal and small farmers. Several factors have played a role in the development of agriculture in the country. The use of high-pay inputs like high yielding varieties seeds, fertilizers, pesticides, irrigation, etc., have helped is bringing about the 'Green Revolution' in agriculture. Though the role of these inputs was recognized long back, there were many constraints were slowly overcome. India being a vast country with varying situation and lack of infrastructure facilities, supply of key inputs in agriculture to the doors of farmers is a difficult task. However, the major sources of supply of farm inputs to the farmers are the dealers. 
These dealers mostly supply seeds fertilizers and pesticides to the farmers.

Modernization of agriculture involves mainly three things. First to evolve suitable agricultural technology, second transfer of technology and third one is acceptance or adoption of technology. The most of the farm input dealers are related to the transfer of farm technology. While trading the farm inputs, dealers advise the farmers about their use and application in the field. Farm input dealers by this way perform the function of the "Change Agent".

India has around three lakh agricultural input dealers (Anonymous 2011) ${ }^{[3]}$. Farm input dealers are also playing an important role in increasing agricultural production in the country. Because they affects the farmers adoption behavior regarding the use of agricultural technology. There are number of economical, social and psychological factors which influence training need of agricultural input dealers as far as selling of agricultural input is concerned. The main aim of input dealers is to sale agricultural inputs according to local needs i.e. quality seeds, fertilizers, pesticides, and input material. The marketing of agricultural inputs does not only help the dealers to increase their profitability but also facilitate to get all the input requirements under the one roof. And the subsidiary roles played by agricultural input dealers are to provide expert services, advice to farmers. These, input dealers plays a vital role to boost up the agricultural production. So it is felt necessary to study the training need of agricultural input dealers.

The study was focused to know the nature and extent of advice and expert services provided by these input dealers to farmers along with supply of input, training needs and constraints of the dealers in transfer of farm technology and running the agriculture input center.

\subsection{Objectives}

Keeping in view the importance, scope and statement of problem of the topic, the present investigation entitled 'Training Needs of Farm Input Dealers About Farm Input in both Akola and Wardha Districts of Vidarbha Region' was undertaken with the following objectives.

1. To ascertain the knowledge level of farm input dealers about the use of farm input they deal.

2. To know the constraints experienced by farm input dealers.

\subsection{Methodology}

The study was conducted purposively in Wardha and Akola districts in Vidarbha region of Maharashtra State. The Wardha district consists of eight tahsils. Out of these five tehsils were selected on random basis namely, Wardha city, Arvi, Deoli, Hinganghat and Seloo. The Akola district consists of seven tehsils. Out of these five tehsils were selected on random basis namely, Akola, Pathur, Barshitakli, Balapur and Akot. A list of licenses issued to the farm input dealers in the tahsils of Wardha and Akola districts was obtained from Agricultural Development Officer, Zilla Parishad of both the districts. Ten tahsils were selected from both the districts. Thus, 10 tahsils comprises the said study, 5 Agro Service Centre from each selected tahsils were selected. In all 50 Agro Service Centre from 10 tahsils and 20 Agro Service Centre from 2 district Headquarters thus, in all 70 Agro Service Centre were selected to the study. An exploratory research design of social research was used for present study.

\section{Results and Discussion}

2.1 Ascertain the knowledge level of farm input dealers

Table 1: Specific knowledge level of farm input dealers

\begin{tabular}{|c|c|c|c|}
\hline \multirow{2}{*}{ Sl. No. } & \multirow{2}{*}{ Knowledge level } & \multicolumn{2}{|c|}{ No. of Respondents (n=70) } \\
\cline { 3 - 4 } & & Frequency & Percentage \\
\hline 1 & Different soil types for different crop cultivation & 57 & 81.42 \\
\hline 2 & Improved varieties of different crops & 52 & 74.28 \\
\hline 3 & Seed rate per ha of different crops & 51 & 72.85 \\
\hline 4 & Pest and diseases of different crops & 64 & 91.42 \\
\hline 5 & Different occurrence of pests and insect & 52 & 74.28 \\
\hline 6 & Quantity and doses of different chemical, biological pesticides & 63 & 90.00 \\
\hline 7 & Name and doses of different fertilizers/bio fertilizers & 63 & 90.00 \\
\hline 8 & Storage of farm input & 57 & 81.42 \\
\hline 9 & Agricultural Equipments/ Implements/farm machinery etc. & 54 & 77.14 \\
\hline 10 & Doses of different insecticides and pesticides & 66 & 94.28 \\
\hline 11 & Time of sowing of different crops & 54 & 77.14 \\
\hline 12 & Name and Doses of weedicides pesticides & 67 & 95.71 \\
\hline
\end{tabular}

The data regarding practice wise knowledge of the respondents about farm inputs and its use in Table 1, high level of knowledge about name and doses of weedicides pesticides and doses of different insecticides and pesticides $(95.71 \%)$ and $(94.28 \%)$ followed by pest and diseases of different crops $(91.42 \%)$, quantity and doses of different chemical, biological pesticides and name and doses of different fertilizers/bio-fertilizers having (90.00\%), respectively. The 81.42 per cent of the respondents having knowledge about different soil types for different crop cultivation and storage of farm input, followed by agricultural equipments/implements/farm machinery etc. and time of sowing of different crops $(77.14 \%)$. However, the low level of knowledge was expressed by them about 74.28 per cent of the respondents having knowledge about the improved varieties of different crops and different occurrence of pests and insect and seed rate per ha of different crops $(72.85 \%)$, respectively.

\subsection{Different knowledge level of farm input dealers and their distribution}

The information in respect of knowledge of the respondents is presented in Table 2. 
Table 2: Distribution of the respondents according to their knowledge

\begin{tabular}{|c|c|c|c|}
\hline \multirow{2}{*}{ Sl. No. } & \multirow{2}{*}{ Knowledge } & \multicolumn{2}{|c|}{ Respondents (n=70) } \\
\cline { 3 - 4 } & & Frequency & Percentage \\
\hline 1 & Low & 10 & 13.33 \\
\hline 2 & Medium & 51 & 68.00 \\
\hline 3 & High & 14 & 18.67 \\
\hline & Total & 70 & 100.00 \\
\hline
\end{tabular}

It is noticed from Table 2, that over three-fifth $(68.00 \%)$ of

18.67 per cent of the respondents from 'high' knowledge level the respondents had 'medium' knowledge level, followed by while 13.33 per cent of the

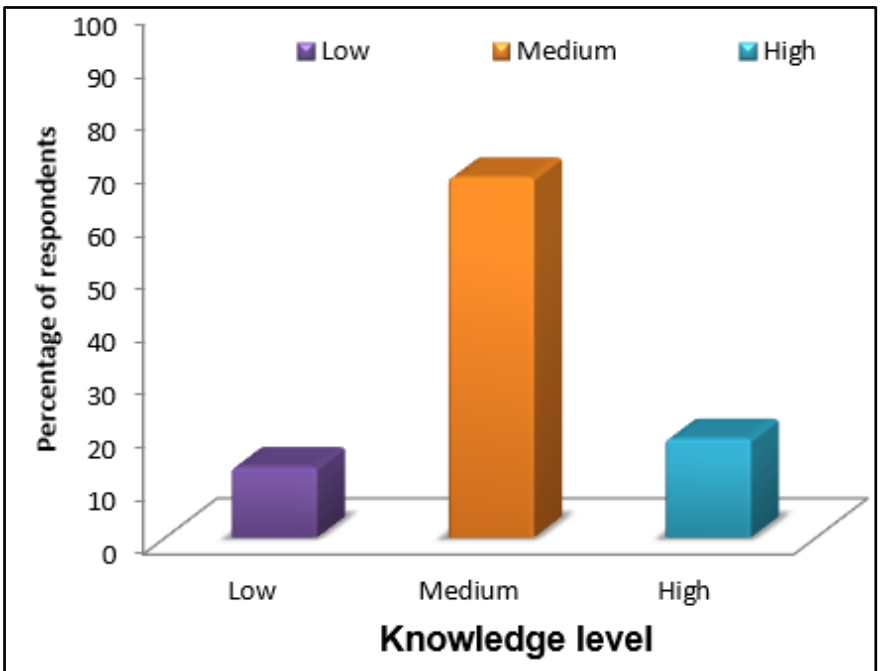

Fig 1: Distribution of the respondents according to their knowledge level

respondents had 'low' knowledge level of the respondents. The average knowledge level score in respect of respondents was 16.10. These findings lead to concluded that majority of the respondents had 'medium' level of knowledge.

Conclusion can be drawn from these findings that the agriculture input dealers from the region were basically more knowledge about farm input.

\subsection{Constraints faced by the farm input dealers}

It was assumed that the agricultural input dealers might be facing some problems in their enterprise. The present study revealed some constraints faced by the respondent dealers; those are listed in Table 3.

Table 3: Constraints faced by the farm input dealers

\begin{tabular}{|c|c|c|c|}
\hline \multirow{2}{*}{ Sl. No. } & Constraints & \multicolumn{2}{c|}{ Respondents (n=70) } \\
\cline { 2 - 4 } & & Frequency & Percentage \\
\hline 1 & To recover the input sold amount from farmer & 51 & 72.85 \\
\hline 2 & Sometime prices of agricultural input goes high & 22 & 31.42 \\
\hline 3 & Detail about content of agrochemicals & 38 & 54.28 \\
\hline 4 & Lack of knowledge about process of manufacturing of agricultural input & 20 & 28.57 \\
\hline 5 & Lack of knowledge about mode of chemicals. & 30 & 42.85 \\
\hline 6 & Competition with other input dealers & 47 & 67.14 \\
\hline 7 & Non availability of selling organizations & 63 & 90.00 \\
\hline 8 & Higher cost of transportation of input & 42 & 60.00 \\
\hline 9 & Place of selling of agricultural inputs & 56 & 82.85 \\
\hline 10 & Non availability of labors & 14 & 20.00 \\
\hline 11 & Non availability of clients & 50 & 71.42 \\
\hline 12 & Dialogue and discussion with farmers, extension functionaries, company representative and farmers. & 18 & 25.71 \\
\hline 13 & & 51 & 72.85 \\
\hline
\end{tabular}

It is observed from Table 3 great majority (90.00\%) of the agricultural input dealers had faced the problem of competition with other input dealers followed by transportation $(82.85 \%)$, non-availability of clients and inadequate credit facilities $(72.85 \%)$, non-availability of labors $(71.42 \%)$, lack of knowledge about mode of chemicals $(67.14 \%)$, non-availability of selling organizations $(60.00 \%)$, sometime prices of agricultural input goes high $(54.28 \%)$ and considerable number of the dealers faced the constraints namely 'lack of knowledge about process of manufacturing of agricultural input', 'to recover the input sold amount from farmer', 'detail about content of agrochemicals', 'dialogue and discussion', and 'place of selling of agricultural inputs'.

\subsection{Summary and Conclusion}

\section{A. Summary}

\section{Ascertain the knowledge level of farm input dealers}

Majority over three-fifth $(68.00 \%)$ of the respondents had 'medium' knowledge level, followed by 18.67 per cent of the respondents from 'high' knowledge level while 13.33 per cent 
of the respondents had 'low' knowledge level of the respondents. The average knowledge level score in respect of respondents was 16.10 .

\section{Constraints experienced in running the agricultural inputs centers}

Majority $(90.00 \%)$ of the agricultural input dealers had faced the problem of competition with other input dealers followed by transportation $(82.85 \%)$, non availability of clients and inadequate credit facilities $(72.85 \%)$, non availability of labors $(71.42 \%)$, lack of knowledge about mode of chemicals $(67.14 \%)$, non availability of selling organizations $(60.00 \%)$ and sometime prices of agricultural input goes high (54.28\%).

\section{B. Conclusion}

These findings revealed that, majority of the farm input dealers were 'middle' age, with 'medium' experience in farm input dealing, source of information, social participation, innovativeness and cosmopoliteness. Majority of the respondents were 'graduate' and most of them had 'medium' land holding and annual income. All the farm input dealers did 'not received' training on various aspects related to fertilizers, seeds, insecticides, pesticides and implements. Majority $(68.00 \%)$ of the farm input dealers had 'medium' level of knowledge related to use of seeds, fertilizers and pesticides. In respect of training needs, farm input dealers had expressed 'high' training needs on seed technology, different insecticides and pesticides its contents, concentration to be used Storage and keeping quality of insecticides, pesticides and fertilizers, etc., followed by advanced technical information of new agricultural inputs, training about credit/financial management and government policies, rules regulations and taxes related agriculture. 'Competition with other input dealers, followed by transportation, non availability of clients and inadequate credit facilities, non availability of labors, lack of knowledge about mode of chemicals, non availability of selling organizations and sometime prices of agricultural input goes high', were the major constraints faced by them.

\section{Implications}

1. The study has brought out useful information about the personal, socio-economic characteristics of the farm input dealers from the districts of Akola and Wardha districts of Vidarbha region. The information can be used by the input supplying agencies for identifying the prospective farm input dealers and thus, can minimize their efforts for locating the people to promote the use of other farm input.

2. The study has pointed out the major constraints faced by the agricultural input dealers namely, competition with other input dealers, followed by transportation, non availability of clients and inadequate credit facilities, non availability of labors, lack of knowledge about mode of chemicals, non availability of selling organizations and sometime prices of agricultural input goes high.

\section{References}

1. Ajinkyakumar Singh L, Singh SP, Panna RS. Information input behavior of wheat growing farmers in Irrigated tract of Haryana. Indian J Ext. Educ.I, 2006; 1:7-10.

2. Anonymous. Success stories - Agro input promoters and agro-output marketers. Indian Agripreneur. 2002; 1(2):3.

3. Anonymous. All-India Fertilizer Consumption. Indian Journal of Fertilizer, 2011, 156.
4. Babana T. Information sources consultancy and training needs of farmers in arecanut cultivation under Thungabhandra command area in Shimoga district. M.Sc. (Agri.) Thesis. University of agricultural Sciences, Bangalore, 2001.

5. Bite RK, Mankar DM, Lambe SP. Information sources used by the farmers in the farm mechanization. Abstracts published in National Seminar on "Role of Extension Education in Changing Agriculture Secnario" held in Dr. BSKKV, Dapoli on March, 2010; 6-8:9.

6. Borkar RD. Adoption behavior of farmers in respect of biofertilizers. M.Sc. Thesis, (Unpub.), Dr. PDKV, Akola,

7. Darade NW. Training needs of farm input dealers for transfer of agricultural technology in Latur district M.Sc. (Agri.) Thesis, College of Agriculture, Latur, MAU, Parbhani, M.S, 2010.

8. Fuke AB. Role of agro-service centres in agricultural development M.Sc. (Agri.) Thesis (Unpub.) Dr. PDKV, Akola, 2011.

9. Gummagolmath KC, Purushottam Sharma, Shelendra. Training need assessment of officers making in agricultural marketing in India. International $\mathbf{J}$ of Exten. Educ. 2013; 8:63-70.

10. Jalak DV. A study of knowledge and adoption of farm implements evolved by MPKV. Rahuri. M.Sc (Agri.) Thesis, MPKV, Rahuri, M.S., India, 2002.

11. Jonas Shoji Lal Bairwa, Kushwaha, Suresh Bairwa. Agricultural input and service delivery system in India: A Review, 2008.

12. Kadam VY. A study on training needs of farm women on selected technology of home Science. M.Sc. (Agri.) Thesis, (Unpub.), 2004.

13. Kale RA. Training need of farm women in dairy farming. M.Sc. (Agri.) Thesis, (Unpub.), Dr. PDKV, Akola, 2012.

14. Kamala Sarah T, Atchutu Raju K. Problems faced by farm women in managing enterprises. Manage Exten. Res. Rev, 2003, 74-78.

15. Khandare KA. A study on training needs of cotton grower about plant protection measure. M.Sc. (Agri.) Thesis, MAU, Parbhani, 2002.

16. Patil SS. Study on training needs of agro service centres owners in Parbhani district. M.Sc. (Agri.), Thesis, MAU, Parbhani, 2004.

17. Patil SS, Bhople PP, Thakare UG. Information Input Behaviors of Facilitators about IPM Technology of Cotton Crop. Asian J of Exten. Educ. 2007; 26(1\&2): 8694.

18. Patil SS, Deshmukh BA, Kharde PB. Training Need Assessment of Subject Matter Specialists of KVKs. Abstracts published in National Seminar on "Role of Extension Education in Changing Agriculture Secnario" held in Dr. BSKKV. Dapoli on March. 2010; 6-8:9.

19. Shelar SA, Nisal BV, Rasal PH, Sananse SL. Study of knowledge assessment and training needs of RCF dealers for effective sale of fertilizers. J Maharashtra Agric. Univ. 2007; 32(3):375-377.

20. Shelke PS, Chikhale NJ, Deshmukh AN, Bhosale SR. Training need of agricultural input dealers for transfer of technology. Agric. Update. 2015; 10(2):105-108. 